\title{
The Role of Financial Services Authorities in Strengthening the Banking Industry in Indonesia (Study During the Covid-19 Pandemic)
}

\author{
Ririt Iriani Sri Setiawati ${ }^{1 *}$, Arin Yuni Pusporini $^{2}$ \\ ${ }^{1}$ Department of Economic Development, Faculty of Economics and Business, Universitas Pembangunan Nasional \\ "Veteran" Jawa Timur, Surabaya 60294, Indonesia \\ ${ }^{2}$ SMK Negeri 10 Surabaya
}

${ }^{*}$ Corresponding author:

E-mail:

ririt.iriani.ep@upnjatim.ac.id

\begin{abstract}
The purpose of this study is to determine the role of the Financial Services Authority in strengthening the Banking Industry in Indonesia during the Covid-19 Pandemic. Qualitative research based on library research is the method used in this research. The type of library research used is textbook analysis. The results of the study show that during the COVID-19 pandemic, OJK has issued several policies to maintain payment traffic flow and financial stability. And the Bank's financial institution
\end{abstract}

Keywords: OJK, Banking, Pandemic, Covid 19

\section{Introduction}

At the end of 2019, the first corona virus appeared in the city of Wuhan, mainland China and spread all over the world. Corona virus is spreading all over the world in a very fast time. According to Putri (2020) Corona virus has become a disease outbreak that is not easy to control, so the WHO (World Health Organization) has made it a global pandemic. Based on JSC news (2021), the Covid 19 Handling Task Force in Indonesia explained that new variants were spreading in Indonesia. These variants are known as the Alpha variant, Beta variant and Delta variant. The Delta variant from India contributed the most cases to the second wave in Indonesia. Where in July 2021 the number of active cases was 545.447 (11.52\%) (Covid-19 Task Force, 2021)

The government issued various regulations in response to this pandemic. The first policy that was issued was Large-Scale Social Restrictions which started first in the Capital area, then the government tried to make gradual easing with the transitional PSBB policy, the next step was the policy of Enforcement of Restrictions on Community Activities or abbreviated as PPKM, PPKM volume one and PPKM volume two, considering the handling of this pandemic. still not effective, the government continues with PPKM with a smaller scope, namely micro PPKM, then Emergency PPKM is carried out as a response to the unequal handling of each region and the next policy is PPKM level starting from level one to the highest level 4.

According to Ridho (2020), the Emergency PPKM Policy hurts business activities. The business world is dim and not a few business actors have to terminate their employment (PHK) for their employees because they are unable to provide wages or salaries and even many entrepreneurs have gone bankrupt. One example is in the Banten area, there are around 800 industries that have to admit defeat in the face of the COVID-19 pandemic. The negative impact was also felt in the tourism industry, whereas of May 2020 throughout Indonesia there were mass closures of hotels reaching 1500 hotel

\section{How to cite:}

Setiawati, R. I. S., \& Pusporini, A. Y. (2021). The role of financial services authorities in strengthening the banking industry in Indonesia (Study during the covid-19 pandemic). $3^{\text {rd }}$ Economics, Business, and Government Challenges 2020. NST

Proceedings. pages 24-32. doi: 10.11594/ nstp.2021.1305 
units, transportation services, travel agents, tourist attractions, and others (Supriyatna \& Fauzi, 2020). The financial sector has not been spared the impact of the COVID-19 pandemic, especially financial institutions where liquidity and insolvency are big problems that must be faced (Ramadhan, 2020). One of the main activities of financial institutions is to distribute credit to the public for business financing, but during the COVID-19 pandemic, its role began to weaken (Maulidya, 2021).

Turbulence in the financial sector is a threat to the nation's economic growth. Thus, it is necessary to have an institution that functions as a control in the financial sector, for example, the establishment of the Financial Services Authority (OJK). This institution has the task of regulating and controlling financial institutions in Indonesia. In addition, OJK also has the task of supervising the banking world from cases of banking crimes, bank management, and human resources (Widhiadnyani, 2016).

During the COVID-19 pandemic, OJK is not just silent. OJK issued policies on the 2020-2025 Indonesia Banking Development Roadmap (RP2I) to maximize the role of banking during the pandemic. From the description above, the author is interested in discussing "The Role of the Financial Services Authority in Strengthening the Banking Industry in Indonesia (Studies During the Covid-19 Pandemic).

\section{Material and Methods}

\section{Financial services authority}

The definition of the Financial Services Authority when viewed from the aspect of OJK regulation no. 21 yrs. 2011 which is an independent institution with functions, duties, authorities in regulating, controlling, examining, and conducting investigations in the financial sector. The authority of OJK is stated in the form of POJK and SEOJK. OJK's activities are banking, capital market, and INBK (Non-Bank Financial Industry). INBK for example fintech, financial institutions, microfinance institutions, pension funds, and insurance, as well as other financial services.

Following the Law on OJK No. 21 of 2011, the OJK has the authority to carry out its duties as regulator and control in the banking sector, namely: the authority to establish licensing procedures, to establish provisions, to supervise, to impose sanctions, to conduct investigations, and to protect consumers.

The compliance/Compliance Based Supervision and Risk/Risk-Based Supervision approaches are approaches used by OJK to conduct supervision. The credit risk, market risk, liquidity risk, and operational risk, legal risk, reputation risk, strategic risk, compliance risk, return risk, and investment risk, intra-group transaction risk, and insurance risk are risk orientation. as a basis for monitoring. And POJK and SEOJK form OJK's authority to act as regulators and supervisors of banking activities in Indonesia so that economic stability remains stable during the COVID-19 pandemic, especially in the financial services sector.

In 2020, in the banking sector, OJK issues and stipulates 11 POJK and 5 SEOJK. To maintain stability, OJK initially set PJOK 11/POJK.03/2020. The purpose of establishing PJOK 11/POJK.03/2020 is to stimulate the economy to spur banking performance that focuses on intermediation, economic stability, and economic growth due to the Covid-19 pandemic. Borrowers affected by the pandemic, especially MSMEs, are the targets of this policy. The policies provided provide credit relaxation everywhere while maintaining the principle of prudence and taking into account the existing regulations. The tourism, hotel, transportation, trade, agriculture, and mining sectors are sectors that are subject to policy 11/POJK.03/2020.

Relaxation of credit or financing can be done through, extending the credit term, reducing interest rates, reducing arrears of principal and interest, and converting loans into temporary equity participation as well as adding credit or financing facilities.

\section{Financial Activities of the Banking Sector}

Financial institutions are institutions that provide direct financial services to customers, banks, stockbrokers, insurance, venture capital, asset management, cooperatives, pension funds, and others. 
Financial Services Institutions from the regulatory aspect (Law on OJK No.21 of 2011) describe institutions that carry out their activities in Insurance, Capital Markets, Pension Funds, Banking, and Financing Institutions, as well as Other Financial Services Institutions. as a regular and supervisor of financial services, the scope of OJK consists of the capital market sector, the banking sector, and the non-bank financial industry. The Non-Bank Financial Industry is a collection of Non-Bank Financial Services Institutions (NBFIs) whose business activities are in the pension fund, insurance, and financial institutions sector, as well as other financial service institutions (SEOJK, 2016).

The definition of Banking according to the Law on OJK of 2011 is anything related to banks, institutions, business activities, as well as methods and processes in carrying out their business activities, both conventional and sharia. Banks are financial institutions that collect funds or receive money deposits from customers who will then lend these funds to customers who need them in the form of credit and also issue promissory notes (banknotes) for the welfare of the wider community.

Based on their function, Banks consist of three types, namely Central Banks, Commercial Banks, and Rural Banks. The three types of banks, both conventional and sharia, are under the supervision of the OJK. Banks whose activities are still conventional are Conventional Banks consisting of Conventional Commercial Banks (BUK), Rural Banks (BPR), and Sharia Business Units.

The health of a bank can be assessed from the analysis of the capital adequacy ratio, loan to deposit ratio, maximum credit limit, small business loans, and the formation of receivable reserves.

\section{Research methods}

This research is qualitative research with a literature study. Qualitative research according to Bogdan and Biklen (2007) is research that embodies descriptive data in the form of writing or behavior and speech of people who are observed in a certain context which is studied from an overall, holistic and comprehensive point of view. According to Hamzah (2019), a literature study is a research procedure that produces data in the form of writing or behavior and speech of people who are observed in a certain context which is studied from an overall, holistic and comprehensive point of view.

The type of library research used is textbook analysis. Textbook analysis in this study comes from articles, journals, OJK reports, regulations, and so on. The reasons for using this library research method are:

a. Data sources are not always available in the field but some are only available from libraries or documents in written form such as journals, books, or other literature.

b. For cases of new symptoms/events that are difficult to understand, a literature study is needed to understand them when formulating concepts in solving these problems.

\section{Results and Discussion}

\section{The covid-19 pandemic and the condition of the banking industry in Indonesia}

The Covid-19 pandemic has left a deep scratch of pain for the people of the world, including the motherland. Information from the Indonesian Ministry of Health shows that active (positive) Covid-19 cases continue to decline until as of October 17,2021 , to 18,388 , while daily recoveries are 1086 . The total number of patients who have recovered since the first case reached $4,073,418$. The target of the vaccination program is $208,265,720$ people, while the number of recipients of the first vaccine is $107,503,228$ people, the recipients of the second vaccine are $62,732,568$ and the number of recipients of the third vaccine is $1,070,061$ people. The following is updated data on the development of Covid19 cases (The Indonesian Ministry of Health, October 2021). 


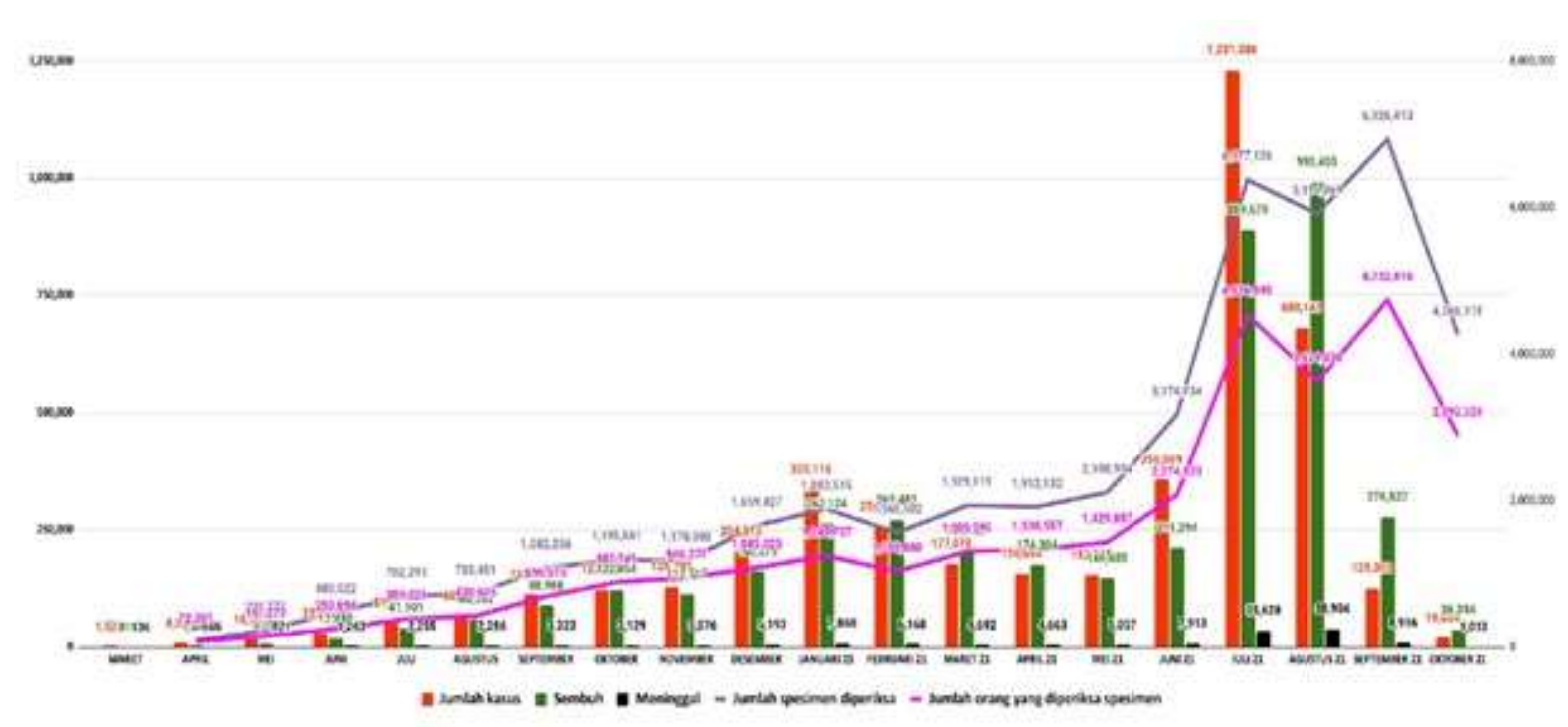

Figure 1. Monthly covid-19 data development statistics

Based on the graph of the development of Covid-19 until October 17, 2021, it shows a better direction. The handling of Covid-19 that is increasingly under control, does not mean that we will soon be free from this pandemic. According to Dicky Budiman, an Epidemiologist from Australia's Griffith University, Indonesia at the end of 2021 will face the third wave of Covid-19 which is triggered by increased community mobility accompanied by a lack of compliance with health protocols.

The covid-19 pandemic imprisoned almost all businesses, the most depressed were the tourism, hospitality, transportation businesses which were unable to operate during the Covid-19 pandemic. The business sector that will also be affected by the pandemic is the banking sector, marked by a slowdown in credit or financing in this sector. Liquidity risk and credit risk in the banking sector can be identified from:

1. Conditions of Performance of Conventional Commercial Banks

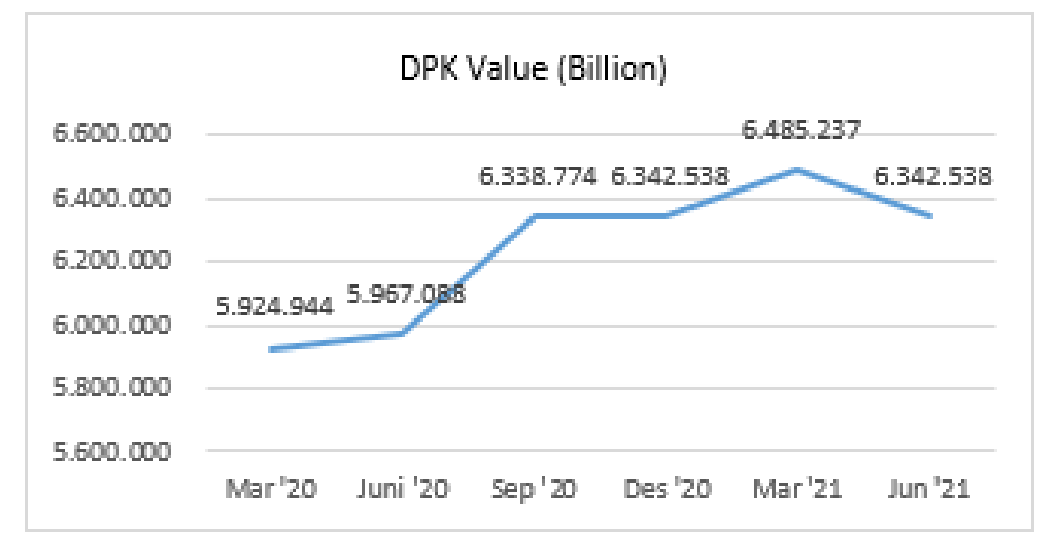

Figure 2. Statistics of Development of DPK Value of Conventional Commercial Banks 


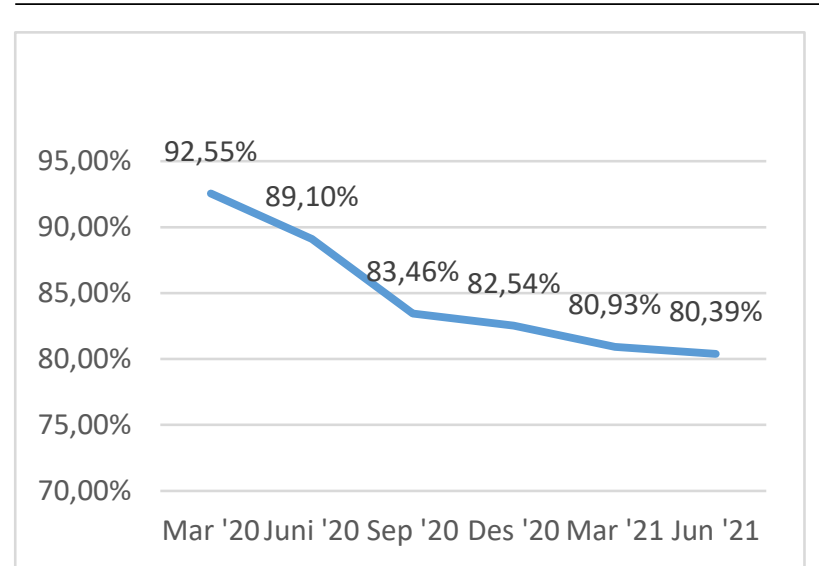

Figure 3. LDR Statistics

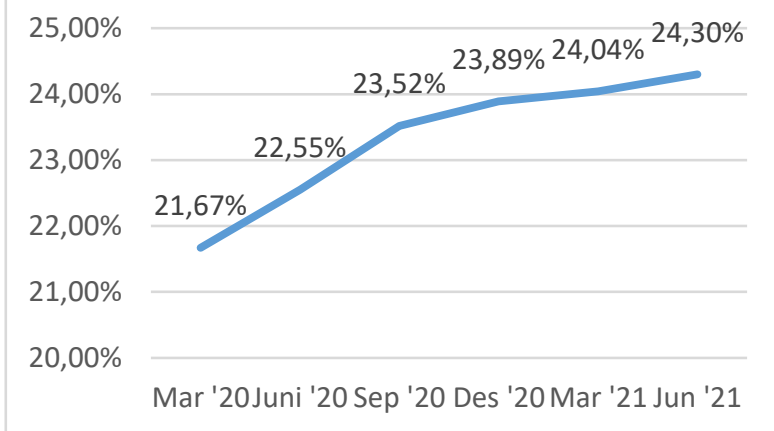

Figure 4. CAR Statistics

Financial intermediation is the main function or spirit of banking. Where this function collects funds from the community (DPK) then distributed them to people who need them in the form of credit (loans) or other forms (Nisaputra, 2021). The level of public trust in conventional banks is still said to be good during the Covid-19 pandemic, this can be seen from the increase in the value of their third party funds, in March 2020 of 5,924,944 (in billions) an increase in June 2021 to 6,342,538 (in billions).

Liquidity is needed to see the extent to which customers can pay their obligations. The liquidity assessment here uses an LDR indicator. The LDR value of Commercial Banks for the Second Quarter of 2020 is $89.10 \%$ (in high risk or the threshold of 78\%-92\%). The third and fourth quarters of 2020 are $83.16 \%$ and $82.54 \%$, respectively (close to the lower threshold of $78 \%-92 \%$ ), the first and second quarters of 2021 are $80.93 \%$ and $80.39 \%$ (close to the lower threshold of $78 \%-92 \%$ ). The higher the ratio number shown, the lower the liquidity capability. This decline indicates a safer liquidity capability.

Performance Conditions of Conventional Commercial Banks during the Covid-19 Pandemic. Capital Resilience is assessed using CAR which is a capital adequacy ratio to measure the ability of banks to channel funds in overcoming the possible risk of loss. The condition of banking resilience in general in the second quarter of 2020 was still maintained, as reflected in the condition of bank capital which was quite solid with a CAR of 22.50 percent. This shows that the bank's ability is quite adequate in absorbing risk. During the fourth quarter of 2020, it was still maintained, as reflected in the bank's fairly solid capital with a CAR of 23.81 percent. The banking industry entering Quarter II 2021 can still be said to be quite good, this is shown by the ability of banks to face risks assessed from the CAR (Capital Adequacy Ratio) of 24.30 percent.

2. Sharia Bank Performance Conditions

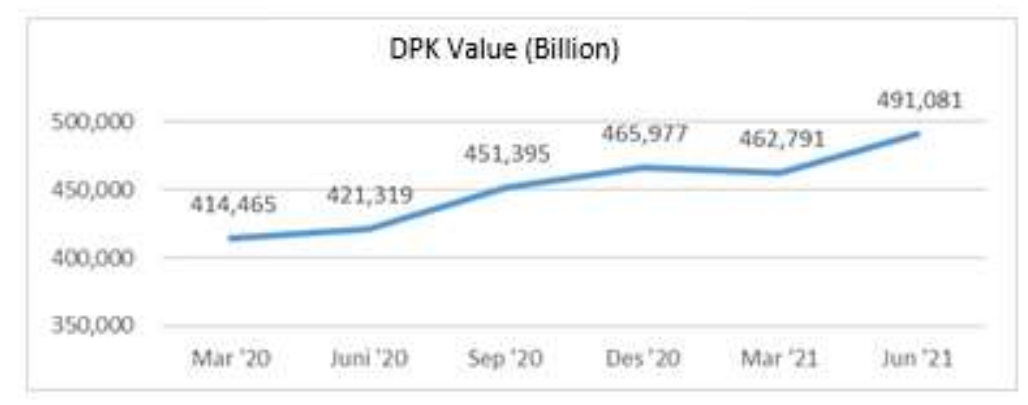

Figure 5. Statistics on Development of Sharia Bank TPF Value 


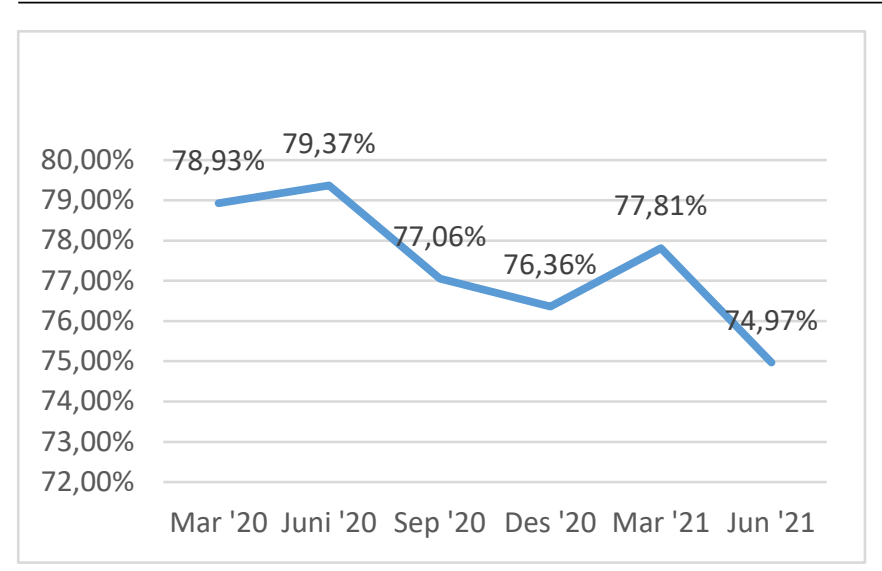

Figure 6. LDR Statistics

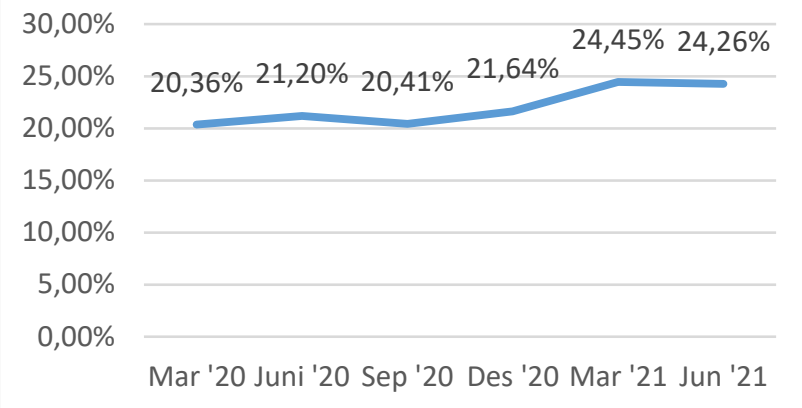

Figure 7. CAR Statistics

In Islamic banking, the term credit is not known, but it is known as financing. The term LDR is used for conventional, while FDR is for Islamic banks. FDR or LDR is the ratio of financing to third-party funds received by the bank.

During the pandemic, the level of public trust in Islamic banks is still relatively high. This is marked by an increase in the value of TPF from March 2020 with a value of Rp. 414,465 (in billions) to Rp. 491,081 (in billions). This increase in third-party funds sourced from the community encourages the FDR Ratio to grow healthier. FDR decreased from 78.93\% in March 2020 to $74.97 \%$ in June 2021. This indicates good bank liquidity and is followed by an increasing CAR chart. This increase shows the good performance of Islamic Banks in increasing revenue and profits.

3. Rural Bank's Performance Condition

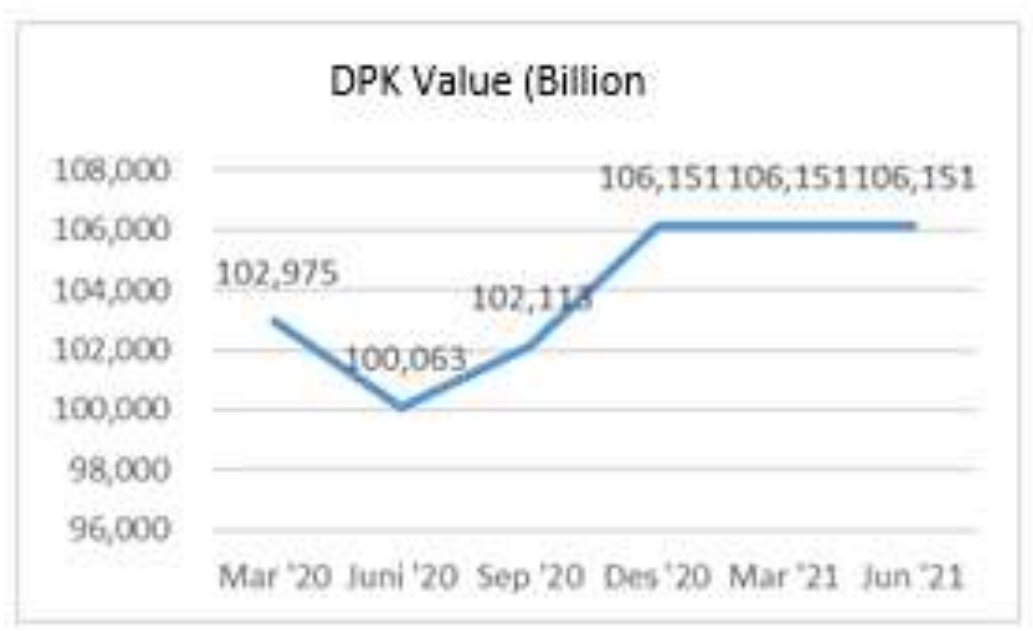

Figure 8. Statistics on Development of Rural Bank Deposit Values 


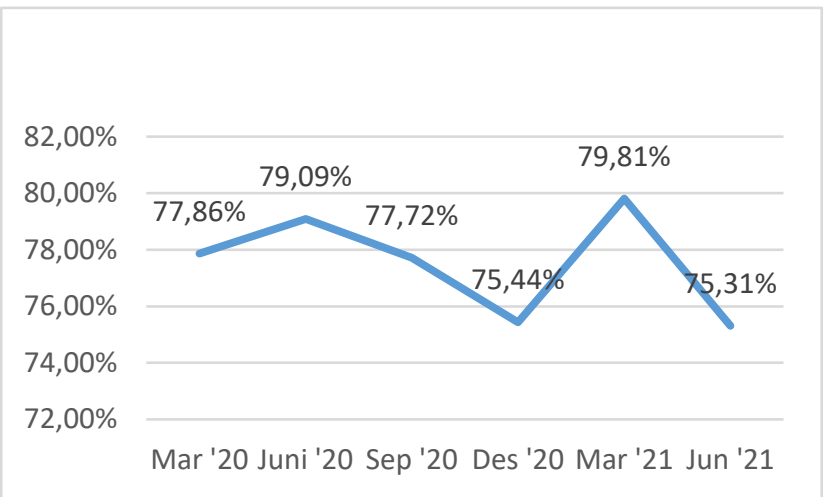

Figure 9. LDR Statistics

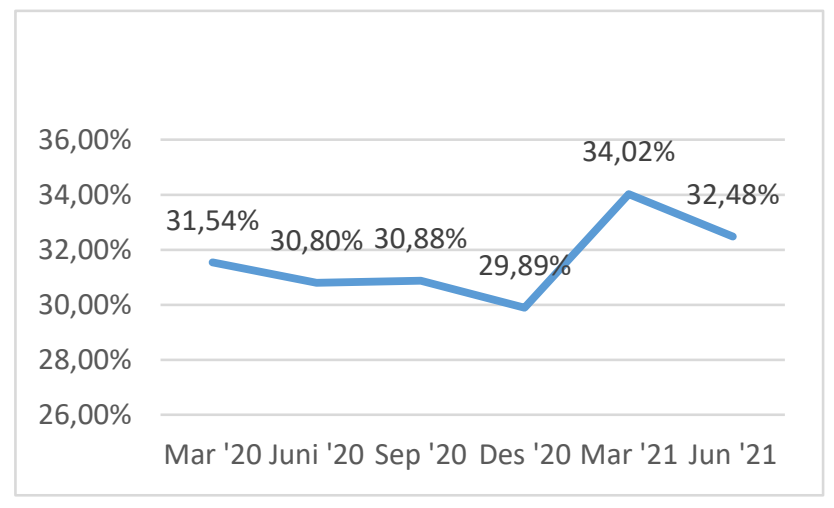

Figure 10. CAR Statistics

The number of third-party Funds still increased from Rp. 102,975 (in billions) in March to Rp. 106,151 (in billions) although in June it experienced a decline. The addition of these funds made BPR experience a decrease in LDR from 77.86\% in March 2020 to $75.31 \%$ in June 2021. This indicates that the level of liquidity is still safe. Likewise, CAR has increased from 31.54\% in March 2020 to $32.48 \%$ in June 2021. Thus, Rural Banks are still able to survive during this pandemic.

\section{OJK's Role in the Indonesian Banking Industry}

The economy of a nation cannot be separated from the contribution of its financial system. The financial system acts as a liaison between people who have more money to give back to people who need money. This activity is intended for investment activities, trading activities, or other activities. A stable financial system encourages a smooth process of allocation of funds so that it will increase economic growth. Meanwhile, if there is instability, it will cause vulnerability to various problems that can become a barrier in the rotation of the economy.

OJK as an institution that has the authority to regulate and supervise all activities in the financial services sector including banking has a major role in dealing with economic problems in the financial services sector, especially the banking industry.

The main factors that will characterize the development and growth of the banking industry, each of which requires appropriate policy support.

1. Consumers of financial services products will demand services that are faster, more flexible, with more varied products, including the interchangeability of credit instruments with the capital market and money market instruments.

2. Banking readiness in increasing investment and lending, especially in the manufacturing, infrastructure, and energy sectors, to revitalize and renew industrial capacity to produce superior value products.

3. Changes in the banking industry regulatory map that demands comprehensive reforms, including liquidity, capital structure, securitization, and governance to prevent the possibility of institutional failure.

4. Integration of the ASEAN banking sector in 2020. To anticipate this, OJK will clarify the direction of banking business activities and increase competitiveness to take advantage of the ASEAN market.

OJK's focus on policies and initiatives (BPI, 2021) include:

1. National Economic Recovery Program Stimulus Policy

In support of PEN, OJK has extended policies related to credit restructuring and financing, especially to help the community, the informal sector, MSMEs, and business actors affected 
by Covid-19 which is carried out repeatedly until March 31, 2023. Providing financing facilities for MSMEs, for example with the Credit program People's Business (KUR). Development of Micro Waqf Bank, KUR, securities crowdfunding platform and digital marketplace.

As of April 26, 2020, 65 Conventional/Sharia Commercial Banks have implemented this policy. A total of 561,950 debtors have been successfully restructured with a total restructuring value of Rp113.8 T and for MSME debtors as many as 522,728 with a total restructuring value of Rp60.9T.

2. Strengthening the Resilience \& Competitiveness of the Financial Services Sector

Accelerating the consolidation process through the implementation of a minimum capital policy in stages and strengthening the implementation of good governance and risk management. Stipulation of policies Number 12/POJK.03/2020 and 18/POJK.03/2020 in strengthening the structure, resilience, competitiveness of the banking industry by consolidating or merging.

3. Financial Services Sector Ecosystem Development

Continuing the capital market development policy by maintaining market integrity and developing the retail and domestic investor base, Supporting financial service institutions to conduct multi-activities and digital-based business, Accelerating the expansion of financial access, and increasing public financial literacy through KUR, BWM, Laku Pandai, and Student Savings as well as strengthening consumer protection, implementing Sustainable Finance through the Roadmap of Sustainable Finance Phase II 2021-2025 and increasing the capacity of human resources in the financial services sector guided by the blueprint for developing human resources in the financial services sector 2021-2025.

4. Acceleration of Digital Transformation in the Financial Services Sector

Encouraging the digitization of products and business processes in the financial services industry, including granting permission for financial service institutions to have a fully digital business (digital bank). Strengthen prudential rules for fintech peer-to-peer lending (P2P lending) by increasing the minimum capital for P2P Lending and implementing Fit \& Proper Tests for its administrators. Supporting the growth of fintech start-ups by developing a regulatory sandbox that applies the same business, same risks, same rules applied principles to minimize regulatory arbitrage. Setting up a Sharia financial product ecosystem by digitizing sharia products, increasing the scale of the sharia financial business, and expanding public access to sharia financial products.

5. OJK Internal Capacity Strengthening

Develop integrated supervision of all aspects of financial services including digital products, as well as monitor potential risks originating from outside the financial services sector and corporate companies, adjust the market conduct supervision process associated with the product life cycle stages, and strengthen digital-based supervision and surveillance business processes through business process reengineering supported by strengthening data management integration.

One of the challenges facing banks today is that the existing banking structure in Indonesia is still relatively small and competitiveness is still low. Environmental changes due to the Covid-19 pandemic require banks to be more responsive to digital services, internal improvements regarding regulation, control, licensing (BPI, 2021). One of how OJK responds to this challenge is by issuing regulations such as regulations No. 12/POJK.03/2020 and 18/POJK.03/2020 which are expected to strengthen the structure, resilience, and competitiveness of the banking industry by consolidating or merging. can compete regionally and globally. The next regulation to answer the challenges faced by the banking industry is the issuance of regulation no. 13/POJK.03/2020. This regulation applies to how to manage IT risk management, and as a support in the Bank's electronic system so that it is expected to increase operational effectiveness and efficiency and provide the best service. 


\section{Conclusion}

The Financial Services Sector during the Covid-19 pandemic was still relatively stable, this can be seen in the financial performance of the conventional general banking industry, Islamic banks, and rural banks. This is inseparable from the efforts made by OJK by issuing policies during the Covid-19 pandemic. One of the policies that have been issued is the policy of restructuring credit and financing (leasing) which will continue to be extended until March 2023. Responding to the challenges for the growth of sharia banking and realizing financial sector stability, synergistic cooperation is needed between government institutions, OJK, Bank Indonesia or other parties. which is related.

\section{References}

Hamzah, A. (2019). Metode penelitian kepustakaan (Library Research). Literasi Nusantara.

JSC, Covid-19. (2021). Varian delta dan hal-hal yang harus kamu perhatikan. Jakarta smartcity.

KementrianPPN/Bapenas. (2021). Studi pembelajaran penanganan covid-19 di Indonesia. Jakarta: KementrianPPN/Bapenas.

Maulidya, F. K. (2021). Securitization: Economic stimulus with strengthening of banking intermediation in facing the covid-19 pandemic. Buletin Riset Kebijakan Perbankan, 2(2), 1-5.

Nisaputra, R. (2021). Kiat mendongkrak fungsi intermediasi sebagai rohnya bank. infobanknews.com. https://infobanknews.com/kiatmendongkrak-fungsi-intermediasi-sebagai-rohnya-bank/

Putri, G. S. (2020). WHO resmi sebut virus corona covid-19 sebagai pandemi global. Kompas.com. www.kompas.com/sains/read/2020 /03/12/083129823/who-resmi-sebut-virus-corona-covid-19-sebagai-pandemi-global?page=all.

Ramadhan, M. I. (2020). Ini 4 sektor yang paling terpukul covid-19. https://mediaindonesia.com/ekonomi/300402/ini-4-sektor-yang-palingterpukul-covid-19

Ridho, R. (2020). 800 industri di Banten bangkrut akibat pandemi Covid-19. Kompas.com. https://regional.kompas.com/read/2020/11/27/06524021/800-industri-di-banten-bangkrut-akibat-pandemi-covid-19.

Satuan Tugas Penanganan Covid-19. (2021). Analisis data covid -19 Indonesia: update per 10 oktober 2021. Jakarta: Satuan Tugas Penanganan Covid-19.

Supriyatna, I., \& Fauzi, A. (2020). 11 bisnis yang paling parah terdampak covid-19. Suara.com. https://www.suara.com/bisnis/2020/ 05/27/144827/11-bisnis-yang-paling-parah-terdampak-covid-19?page=all.

Surat Edaran Otoritas Jasa Keuangan nomor 29 /seojk.05/2016 tentang bentuk dan tata cara permohonan, penyampaian laporan, dan program pendidikan berkelanjutan konsultan aktuaria, akuntan publik, dan penilai yang melakukan kegiatan di industri keuangan nonbank.

Widhiadnyani, N. M. N. (2016). Tanggung jawab otoritas jasa keuangan sebagai pengganti bank Indonesia Dalam Pengawasan Lembaga perbankan. Kertha Semaya, IV(2), 1-5. 